\title{
Net Hydrogenation of Pt-NHPh Bond Is Catalyzed by Elemental Pt
}

\author{
Joanna R. Webb, ${ }^{\dagger}$ Aaron W. Pierpont,$^{\S}$ Colleen Munro-Leighton, ${ }^{\ddagger}$ T. Brent Gunnoe, ${ }^{*, \dagger}$ \\ Thomas R. Cundari, ${ }^{*, \S}$ and Paul D. Boyle ${ }^{\ddagger}$

\begin{abstract}
Department of Chemistry, University of Virginia, Charlottesville, Virginia 22904, Department of Chemistry, North Carolina State University, Raleigh, North Carolina 27695, and Department of Chemistry, Center for Advanced Scientific Computing and Modeling (CASCaM), University of North Texas, Denton, Texas 76203
\end{abstract}

Received December 3, 2009; E-mail: tbg7h@ virginia.edu

The addition of $\mathrm{H}_{2}$ across $\mathrm{M}-\mathrm{NHR}$ or $\mathrm{M}-\mathrm{OR}$ moieties is a central reaction for several synthetic transformations. For example, Stryker's reagent, $\left[\left(\mathrm{Ph}_{3} \mathrm{P}\right) \mathrm{CuH}\right]_{6}$, a catalyst for conjugate addition reactions, is generated by hydrogenolysis of a $\mathrm{Cu}-\mathrm{O}^{t} \mathrm{Bu}$ bond. ${ }^{1,2}$ Additionally, net $\mathrm{H}_{2}$ addition across $\mathrm{M}-\mathrm{O}_{2} \mathrm{CH}$ bonds completes catalytic conversion of $\mathrm{CO}_{2}$ and $\mathrm{H}_{2}$ to formic acid, ${ }^{3} \mathrm{H}_{2}$ addition across $\mathrm{Pt}-\mathrm{OH}$ bonds has been proposed in a cycle for olefin epoxidation, ${ }^{4}$ and $\mathrm{H}_{2}$ addition across $\mathrm{M}-\mathrm{NHR}$ bonds has been implicated in asymmetric hydrogenations. ${ }^{5}$ Despite their importance, reports of well-defined reactions with late(r) transition metal systems are rare and mechanistic studies are limited. ${ }^{5-8}$ Recently, $\mathrm{C}-\mathrm{H}$ activation of hydrocarbons via net 1,2-addition of $\mathrm{C}-\mathrm{H}$ bonds across metal-heteroatom bonds using late transition metals (with $\geq 6$ d-electrons) bearing formally anionic ligands (e.g., - NHR or -OR) has been reported. ${ }^{9-14}$ Despite interest in these $\mathrm{C}-\mathrm{H}$ and $\mathrm{H}-\mathrm{H}$ bond transformations, questions regarding the mechanism remain. ${ }^{10,15-17}$

The complex [( $\left.\left.{ }^{\mathrm{t} p p y}\right) \mathrm{Pt}(\mathrm{Me})\left(\mathrm{NH}_{2} \mathrm{Ph}\right)\right]\left[\mathrm{O}_{2} \mathrm{CCF}_{3}\right](\mathbf{1})$ is formed upon reaction of aniline and ( $\left.{ }^{t} \mathrm{bpy}\right) \mathrm{Pt}(\mathrm{Me})\left(\mathrm{O}_{2} \mathrm{CCF}_{3}\right)^{18}$ ('bpy $=4,4^{\prime}$-ditert-butyl-2,2'-dipyridyl). The deprotonation of $\mathbf{1}$ produces ( ${ }^{\mathrm{b} p \mathrm{~b} y}$ )$\mathrm{Pt}(\mathrm{Me})(\mathrm{NHPh})$ (2). For 2, a broad singlet is observed at $3.99 \mathrm{ppm}$ $\left({ }^{1} \mathrm{H}\right.$ NMR) due to the amido proton. The methyl ligand resonates at $1.85 \mathrm{ppm}$ (singlet with Pt satellites, ${ }^{2} J_{\mathrm{Pt}-\mathrm{H}}=84 \mathrm{~Hz}$ ) in the ${ }^{1} \mathrm{H}$ NMR spectrum and at $-14.2 \mathrm{ppm}$ (singlet with Pt satellites, ${ }^{1} J_{\mathrm{Pt}-\mathrm{C}}$ $=813 \mathrm{~Hz})$ in the ${ }^{13} \mathrm{C}\left\{{ }^{1} \mathrm{H}\right\}$ NMR spectrum. The solid-state structure of 2 (Figure 1) confirms its monomeric nature.

Reactions of a benzene solution of $\mathbf{2}$ pressurized with $\mathrm{H}_{2}$ at room temperature ultimately produce free ${ }^{t}$ bpy ligand, methane, and aniline. Careful monitoring of the reaction at $45 \mathrm{psi}$ of $\mathrm{H}_{2}$ revealed the formation of ( $\left.{ }^{t} \mathrm{bpy}\right) \mathrm{Pt}(\mathrm{Me})(\mathrm{H})(3)$ as an intermediate (Scheme 1 and Figure S4 in the Supporting Information). For complex 3, a hydride resonance is observed at $-14.8 \mathrm{ppm}\left({ }^{1} J_{\mathrm{Pt}-\mathrm{H}}=1575 \mathrm{~Hz}\right)$ in the ${ }^{1} \mathrm{H}$ NMR spectrum as well as a new methyl resonance at $2.21 \mathrm{ppm}\left({ }^{2} J_{\mathrm{Pt}-\mathrm{H}}=83 \mathrm{~Hz}\right)$. The mechanism for dihydrogen addition across $\mathrm{Pd}^{\mathrm{II}}-\mathrm{OR}\left(\mathrm{R}=\mathrm{H}\right.$ or $\left.\mathrm{CH}_{3}\right)$ bonds proposed by Goldberg, Kemp, Muller, and Fulmer involves 1,2-addition of $\mathrm{H}_{2}$ across the $\mathrm{Pd}-\mathrm{OR}$ moiety, via a $\sigma$-bond metathesis type transition state, to produce $\mathrm{ROH}$ and a $\mathrm{Pd}^{\mathrm{II}}-\mathrm{H}$ complex. ${ }^{8}$ Thus, reaction of $\mathrm{H}_{2}$ with 2 via a similar mechanism would involve $\mathrm{Pt}$ mediated 1,2-addition of $\mathrm{H}_{2}$ to give ( $\left.{ }^{t} \mathrm{bpy}\right) \mathrm{Pt}(\mathrm{Me})\left(\mathrm{NH}_{2} \mathrm{Ph}\right)(\mathrm{H})$ with aniline dissociation to form $\mathbf{3}$ and subsequent decomposition of $\mathbf{3}$ to methane, $\mathrm{Pt}(\mathrm{s})$, and free ${ }^{t}$ bpy. We initially presumed this straightforward pathway, which is consistent with the general notion of reactions with related systems. ${ }^{5,7,8,13,19,20}$ Monitoring $\left({ }^{1} \mathrm{H}\right.$ NMR) the reaction of $\mathbf{2}$ with $\mathrm{H}_{2}$ and a plot of [2] versus time reveals an induction period (Figure

\footnotetext{
$\uparrow$ University of Virginia.

$\$$ University of North Texas.

* North Carolina State University.
}

2A). The observation of an induction period led us to consider $\mathrm{Pt}(\mathrm{s})$ as a heterogeneous catalyst. ${ }^{21}$

As an initial probe of a $\mathrm{Pt}(\mathrm{s})$ catalyzed process, we used a standard $\mathrm{Hg}$ test. ${ }^{21}$ The addition of $\mathrm{Hg}$ to a solution of 2 in $\mathrm{C}_{6} \mathrm{D}_{6}$ followed by pressurization with $\mathrm{H}_{2}$ completely suppresses reactivity (see Supporting Information). Next, a solution of $\mathbf{2}$ pressurized with $\mathrm{H}_{2}$ was allowed to react until visible formation of $\mathrm{Pt}(\mathrm{s})$, at which point conversion of $\mathbf{2}$ to $\mathbf{3}$ was observed. The reaction solution was decanted from the tube, a fresh solution of $\mathbf{2}$ in $\mathrm{C}_{6} \mathrm{D}_{6}$ was added to the original NMR tube and pressurized with $\mathrm{H}_{2}$, and the reaction was followed by ${ }^{1} \mathrm{H}$ NMR. A plot of [2] versus time reveals no induction period (see Supporting Information). Maitlis' test ${ }^{22}$ was performed by monitoring the reaction until past the induction period. The reaction tube was then vented, the solution was filtered through Celite, and the filtrate was placed in a clean NMR tube, pressurized with $\mathrm{H}_{2}$, and monitored. Figure $2 \mathrm{~B}$ shows that a second induction period is observed after removal of $\mathrm{Pt}(\mathrm{s})$. As additional confirmation, in a separate experiment $10 \mathrm{wt} \% \mathrm{Pt}$ on activated carbon was added to a solution of $\mathbf{2}$ before pressurization with $\mathrm{H}_{2}$. The consumption of 2 reached $50 \%$ conversion after 5 min and completion in $<1 \mathrm{~h}$. A control experiment with 2 and elemental Pt in the absence of $\mathrm{H}_{2}$ resulted in no reaction.

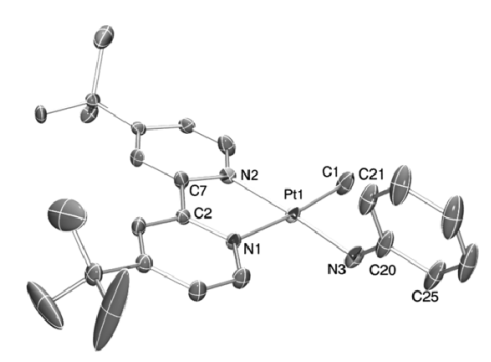

Figure 1. ORTEP of ( $\left.{ }^{\mathrm{b} b p y}\right) \mathrm{Pt}(\mathrm{Me})(\mathrm{NHPh})(2)$ (50\% probability; $\mathrm{H}$ atoms omitted for clarity). Selected bond lengths (Å): Pt1-N1 2.077(2), Pt1-N2 2.026(2), Pt1-C1 2.040(3), Pt1-N3 2.005(2), N3-C20 1.357(4).

Scheme 1. Reaction of (tbpy)Pt(Me)(NHPh) (2) and $\mathrm{H}_{2}$

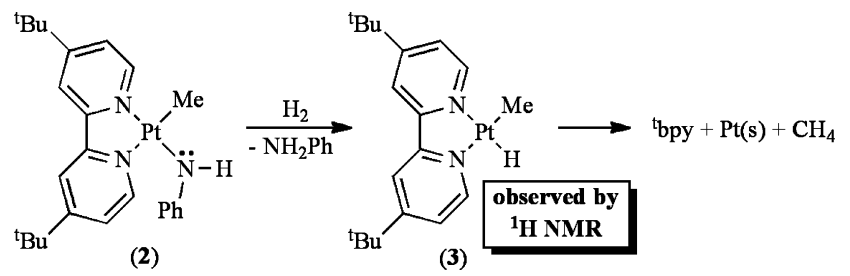

The proposed pathway of $\mathrm{H}_{2}$ addition across the $\mathrm{Pt}-\mathrm{NHPh}$ bond of $\mathbf{2}$ contrasts the proposed mechanism of hydrogenolysis of related $\mathrm{Pd}(\mathrm{II})$ hydroxide and methoxide complexes. ${ }^{8}$ To probe the source of these differences, DFT calculations (B3LYP, pseudopotentials) were 
employed. Reaction of $\mathbf{2}$ and $\mathrm{H}_{2}$ to give $\mathbf{3}$ and aniline is calculated to be exothermic by $6 \mathrm{kcal} / \mathrm{mol}$, but with a barrier of $45 \mathrm{kcal} / \mathrm{mol}$. In contrast, the calculated barrier for $\mathrm{H}_{2}$ addition across the $\mathrm{Pd}-\mathrm{OH}$ bond of (PCP)Pd( $\mathrm{OH})\left\{\mathrm{PCP}=2,6\right.$-bis $\left.\left(\mathrm{CH}_{2} \mathrm{PMe}_{2}\right)_{2} \mathrm{C}_{6} \mathrm{H}_{3}\right\}$, to give (PCP)Pd$(\mathrm{H})$ and water, is $21.0 \mathrm{kcal} / \mathrm{mol}$, despite the similar reaction enthalpy $(-4 \mathrm{kcal} / \mathrm{mol}){ }^{8}$ At the current level of theory, the calculated $\mathrm{H}_{2}$ activation barrier and reaction enthalpy for (PCP)Pd(OMe) $(24$ and $-3 \mathrm{kcal} / \mathrm{mol}$, respectively) are similar to those of the hydroxy analogue.

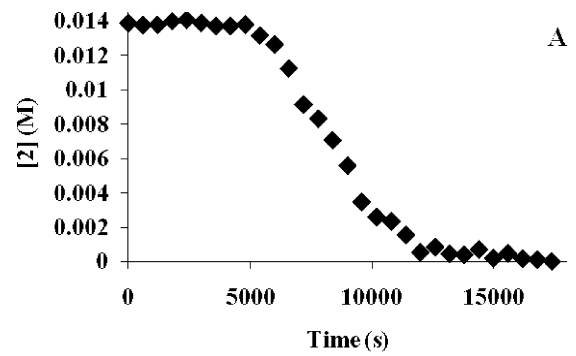

A

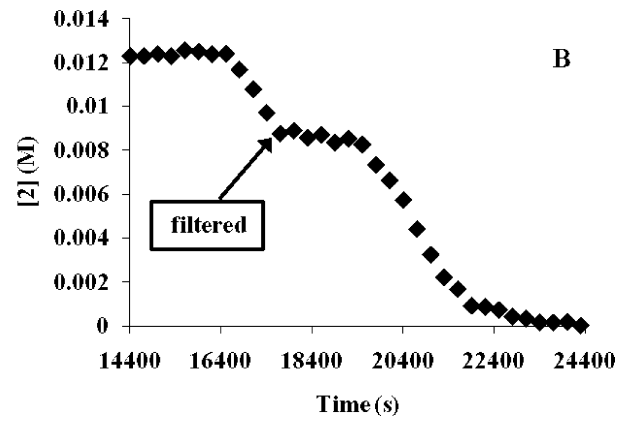

Figure 2. Plots monitoring [2] versus time: (A) $200 \mathrm{psi}$ of $\mathrm{H}_{2}$ at room temperature, (B) reaction solution filtered to remove $\mathrm{Pt}(\mathrm{s})$ after initial induction period (plot started after $14400 \mathrm{~s}$ reaction time).

Figure 3 displays the calculated transition state for $\mathrm{H}-\mathrm{H}$ activation by 2 . For the amido lone pair (conjugated with the phenyl substituent) to orient to receive a $\mathrm{H}$ atom from $\mathrm{H}_{2}$, it must be aligned perpendicular to the $\mathrm{Pt}$ square plane. This orientation would place the phenyl substituent in close proximity to either the Me or the ${ }^{t}$ bpy ligand, which provides a steric inhibition to $\mathrm{H}_{2}$ activation. In the calculated transition state, the phenyl substituent may rotate perpendicular to the amide plane, breaking $\mathrm{C}_{\mathrm{ipso}}-\mathrm{N}$ conjugation. Note the longer bond length of $1.46 \AA$ for the $\mathrm{C}_{\text {ipso }}-\mathrm{N}$ bond in the TS (Figure 3) versus $1.39 \AA$ (calcd., $1.36 \AA$ /experimental) in 2. Comparison of calculated $\mathrm{H}_{2}$-scission barriers for (bpy)M(Me)(N$\mathrm{HPh})(\mathrm{M}=\mathrm{Pd}$ or $\mathrm{Pt})$ and $(\mathrm{PCP}) \mathrm{Pd}(\mathrm{OMe}),($ bpy $) \mathrm{Pt}(\mathrm{Me})(\mathrm{NHMe})$, (bpy) $\mathrm{M}(\mathrm{Me})(\mathrm{OMe})$, and (bpy) $\mathrm{Pt}(\mathrm{Me})(\mathrm{NHPh} *)\left\{\mathrm{Ph}^{*}\right.$ denotes a $\mathrm{Ph}$ in the $\mathrm{MM}$ region of a $\mathrm{QM} / \mathrm{MM}$ calculation $\}$ suggests that the remarkable difference in barriers between (bpy) $\mathrm{Pt}(\mathrm{Me})(\mathrm{NHPh})$ and $(\mathrm{PCP}) \mathrm{Pd}(\mathrm{OMe})$ is due in equal parts to replacement of the metal $(\mathrm{Pt} \rightarrow \mathrm{Pd})$, activating ligand $(\mathrm{NHMe} \rightarrow \mathrm{OMe})$, and supporting ligand (bpy/Me $\rightarrow$ PCP). The predicted enhancement upon substituting $\mathrm{Pd}$ for $\mathrm{Pt}$ might be explained by the anticipated increase in electrophilicity of $\mathrm{Pd}$ (vs Pt), which would facilitate $\mathrm{H}_{2}$ activation. The long $\mathrm{Pt}-\mathrm{H}$ bond distances in the calculated transition state for 2 (Figure 3) are consistent with weak $\mathrm{Pt} / \mathrm{H}_{2}$ activation as one source of a substantial activation barrier. These influences underscore the subtle balance required to access systems that can activate $\mathrm{H}-\mathrm{H}$ and $\mathrm{C}-\mathrm{H}$ bonds. In the transition states for $\mathrm{H}_{2}$ activation by (bpy) $\mathrm{M}(\mathrm{Me})(\mathrm{NHPh})$ the calculated $\mathrm{Pt}-\mathrm{H}$ bond distances are 2.48 and $2.34 \AA$, while the $\mathrm{Pd}-\mathrm{H}$ distances for the TS of the complex reported by Goldberg are indeed shorter, 2.12 and $2.14 \AA \AA^{8}$, despite the near identical covalent radii of $\mathrm{Pd}$ and $\mathrm{Pt}$.
The activation of $\mathrm{H}_{2}$ by ( $\left.{ }^{b} \mathrm{bpy}\right) \mathrm{Pt}(\mathrm{Me})(\mathrm{NHPh})$ (2) produces $\left({ }^{t} \mathrm{bpy}\right) \mathrm{Pt}(\mathrm{Me})(\mathrm{H})(\mathbf{3})$. However, kinetic studies lead to the conclusion that, rather than direct activation of $\mathrm{H}_{2}$ across the $\mathrm{Pt}-\mathrm{NHPh}$ bond, $\mathrm{Pt}(\mathrm{s})$ is catalyzing the hydrogenation of the $\mathrm{Pt}-\mathrm{NHPh}$ moiety, though the specific mechanism of this transformation is not known. To our knowledge, this is the first report of a heterogeneous catalyst for activation of covalent bonds toward addition across an $\mathrm{M}-\mathrm{X}$ ( $\mathrm{X}=$ NHR or OR) bond and a rare example of net $\mathrm{H}_{2}$ addition to $\mathrm{M}-\mathrm{L}$ bonds by a heterogeneous catalyst. ${ }^{23,24}$

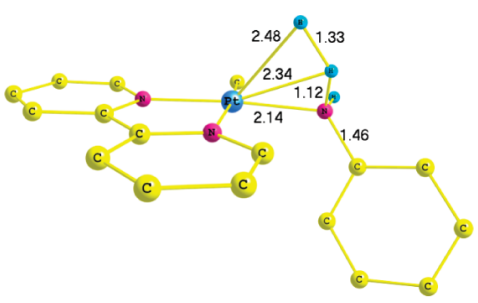

Figure 3. Calculated transition state for activation of $\mathrm{H}_{2}$ by complex 2 . Most hydrogen atoms omitted for clarity.

Acknowledgment. T.B.G. acknowledges the NSF (CHE0848693) for funding. T.R.C. thanks the NSF for support (CHE0701247) and facilities (CHE-0741936). A.W.P. thanks the UNT Toulouse Graduate School for a Dissertation Fellowship.

Supporting Information Available: Characterization data, experimental and computational details including kinetic studies and plots, and X-ray crystallographic data files for $\mathbf{2}$. This material is available free of charge via the Internet at http://pubs.acs.org.

\section{References}

(1) Deutsch, C.; Krause, N.; Lipshutz, B. H. Chem. Rev. 2008, 108, 2916.

(2) Goeden, G. V.: Caulton, K. G. J. Am. Chem. Soc. 1981, 103, 7354

(3) Jessop, P. G.; Joo, F.; Tai, C. C. Coord. Chem. Rev. 2004, 248, 2425.

(4) Wenzel, T. T. Stud. Surf. Sci. Catal. 1991, 66, 545.

(5) Sandoval, C. A.; Ohkuma, T.; Muniz, K.; Noyori, R. J. Am. Chem. Soc. 2003, 125, 13490.

(6) Abdur-Rashid, K.; Faatz, M.; Lough, A. J.; Morris, R. H. J. Am. Chem. Soc. 2001, 123, 7473.

(7) Fryzuk, M. D.; Montgomery, C. D.; Rettig, S. J. Organometallics 1991, $10,467$.

(8) Fulmer, G. R.; Muller, R. P.; Kemp, R. A.; Goldberg, K. I. J. Am. Chem. Soc. 2009, 131, 1346.

(9) Feng, Y.; Lail, M.; Barakat, K. A.; Cundari, T. R.; Gunnoe, T. B.; Petersen, J. L. J. Am. Chem. Soc. 2005, 127, 14174.

(10) Feng, Y.; Lail, M.; Foley, N. A.; Gunnoe, T. B.; Barakat, K. A.; Cundari, T. R.; Petersen, J. L. J. Am. Chem. Soc. 2006, 128, 7982.

(11) Tenn, W. J., III; Young, K. J. H.; Bhalla, G.; Oxgaard, J.; Goddard, W. A., III; Periana, R. A. J. Am. Chem. Soc. 2005, 127, 14172.

(12) Kloek, S. M.; Heinekey, D. M.; Goldberg, K. I. Angew. Chem., Int. Ed. 2007, 46, 4736 .

(13) Conner, D.; Jayaprakash, K. N.; Cundari, T. R.; Gunnoe, T. B. Organometallics 2004, 23, 2724 .

(14) Bercaw, J. E.; Hazari, N.; Labinger, J. A. Organometallics 2009, 28, 5489.

(15) Oxgaard, J.; Tenn, W. J., III; Nielson, R. J.; Periana, R. A.; Goddard, W. A., III. Organometallics 2007, 26, 1565.

(16) Boutadla, Y.; Davies, D. L.; Macgregor, S. A.; Poblador-Bahamonde, A. I. J. Chem. Soc., Dalton Trans. 2009, 5820 .

(17) Cundari, T. R.; Grimes, T. V.; Gunnoe, T. B. J. Am. Chem. Soc. 2007, $129,13172$.

(18) Hill, G. S.; Rendina, L. M.; Puddephatt, R. J. J. Chem. Soc., Dalton Trans. 1996, 1809.

(19) Abdur-Rashid, K.; Clapham, S. E.; Hadzovic, A.; Harvey, J. N.; Lough, A. J.; Morris, R. H. J. Am. Chem. Soc. 2002, 124, 15104.

(20) Yang, J. Y.; Bullock, R. M.; Shaw, W. J.; Twamley, B.; Fraze, K.; DuBois, M. R.; DuBois, D. L. J. Am. Chem. Soc. 2009, 131, 5935.

(21) Widegren, J. A.; Finke, R. G. J. Mol. Catal. A: Chem. 2003, 198, 317.

(22) Hamlin, J. E.; Hirai, K.; Millan, A.; Maitlis, P. M. J. Mol. Catal. 1980, 7, 543.

(23) Miller, T. M.; Izumi, A. N.; Shih, Y. S.; Whitesides, G. M. J. Am. Chem. Soc. 1988, $110,3146$.

(24) Begum, R. A.; Chanda, N.; Ramakrishna, T. V. V.; Sharp, P. R. J. Am. Chem. Soc. 2005, 127, 13494.

JA9102309 